\title{
ON TRUTH OF LINGUISTIC PROPOSITIONS
}

\begin{abstract}
In the present paper I analyse propositions functioning in linguistics from the point of view of the criteria of truth imposed on the propositions within the so-called correspondence theory of truth, coherence theory of truth, and pragmatic theory of truth in its sociological version. There exists in linguistic circulation a certain group of propositions which on some assumptions are in agreement with Tarski's explication. The truth of each sentence from the second group can be predicated only when they are juxtaposed with sentences belonging to a concrete system of propositions. The analysed sentence will be recognised as false in a different system. Some systems of sentences may recognise the criteria of evaluation as inadequate, they are, however, not sufficiently sharp so as to enable to make the final decision about the supremacy of one concrete system of sentences over the others. In linguistics there also exist many sentences which are true in linguists' view, although they are not coherent with a certain system of sentences - the propositions belonging to this system may lead to different conclusions.

It is the last group of sentences that in the eyes of postmodernists constitutes an argument supporting the thesis that in science (particularly in the humanities) we deal only with accumulating narratives. The major objective of this paper is, however, to prove that the propositions which belong to the third group, although frequent in linguistics, do not belong to its centre - they are only a complement of what may be described by the name of linguistic discourse.
\end{abstract}

\section{Introduction}

In the present article I make an attempt to solve one of the most difficult questions not only of contemporary linguistics, but - as I believe - also of contemporary humanities. It may be described more or less as follows: What is the sense of practicing a methodologically disciplined linguistics if - as the very opinion-forming representatives of cognitive science claim - all the humanities are a mere set of (meta)narratives, and narratives do not fall into the traditional categories of truth and falsity. It is only the community of academics who are 
willing to recognise some narratives as true, while rejecting others. However, the selection does not take place on the grounds of a decisive rational evidence, but it is a resultant of various convictions of the researchers. And these, in turn, are formed intuitively and in keeping with the intellectual fashion in vogue at a given moment.

These types of questions are often posed by researchers who are at the threshold of their academic career. I could experience this when conducting classes in linguistic methodology for doctoral students of the Jagiellonian University. Also mature scholars ask themselves similar questions. And it often happens that the answer which comes to their mind changes their former practice. They abandon the disciplined reflection in order to follow intuition and the so-called commonsensical thinking. Since everything in linguistics is only a narrative, it is clear that narratives based on the former procedures must be conventional, and thus less moving than narratives created by intuition.

Many researchers, however, stick to their former methods. Some, for various reasons, do not ask themselves the above question. Those, however, who do, reject the vision of linguistics as a set of metanarratives. Some do not see any empirical grounds for this concept - what is more - they do not even try to look for them. They also say that it is a fashion which will pass sooner or later. Such an approach cannot be denied its raison d'être, although it is obvious that younger researchers will accuse it of dogmatism. It certainly does not encourage a deeper discussion within linguistics.

The postmodernist approach may also be rejected in the way used by other scholars who admittedly see in the postmodernist argumentation many apt observations concerning the functioning of scholarship, but they do not turn postmodernists themselves, since scholarship, which contains many procedures and is a resultant of various opinions, minimalises the risk of a mistake. The author of the present text wishes to be counted among those researchers as well. His ambition is also to find a principle which would be helpful in separating the apt post-modernist assertions from those which cannot be attributed this feature. It appears that the consideration taken up here will prove to be very helpful in this investigation.

Initially, every researcher may quote many examples from his own field which confirm the rightness of the arguments presented by the followers of the narrative character of linguistics and other humanities. To begin with, let us consider a few such arguments in order to subsequently move to the current dilemmas connected with the concept of truth, and in view of these once more reflect on the nature of the propositions existing in contemporary linguistic science, and as a consequence find a key to distinguish a number of categories of these propositions.

The formation of the view that opinions arisen in the area of linguistics are only components of the (meta)narrative was surely influenced by both the views of some influential linguists and conclusions resulting from observations of the changes taking place in the recent decades. 
The fundamental differentiation between an abstract system and a concrete text postulated by the precursors of structuralism as early as the $19^{\text {th }} \mathrm{c}$. had to lead to a conclusion that in truth the subject matter of linguistics is a system which proves inaccessible to direct observation. If this is the case, then the linguist builds only a model (an approximate representation) of this system, moreover, the number of such models can be theoretically infinite. It needs to be added that despite some attempts to establish criteria of assessing the models, in the consciousness of many linguists there has long functioned a view that what is decisive is in principle a fairly indefinable criterion of the elegance of description. Another group of linguists, on the other hand, when assessing models were also motivated by an even more mysterious criterion of the explanatory adequacy.

This lack of decisive criteria resulted in the formulation of newer and newer concepts of language description, and linguists got divided into smaller groupings. This division was intensified by a wide-spread idea that a fruitful discussion may be conducted only within one paradigm. Popper (1997) described this view as a conceptual schema myth and endeavoured to battle against it in the field of philosophy of science. This approach, however, caused the appearance of many incommensurate conceptions in generative linguistics alone with their own notation and terminology. In this state of affairs it is not surprising that relativism became quite well established in linguistics.

In the 1970s and 1980s a number of distinct conceptions of grammatical description with differently defined lexical categories appeared even in Polish linguistics, in which generativism did not play a significant role. Also some competitive conceptions of the grammatical gender evolved, which will be further analysed in this paper.

\section{Three perspectives on truth of propositions}

The argumentation of the advocates of the narrative character of linguistic propositions outlined above is supported by a more general philosophical argumentation formed as a result of questioning the traditional view of truth. Although earlier linguists - as Pelc (2004) believes - were inclined to assume that truth did not play a major role in linguistics because language was used for both telling the truth and telling an untruth, scepticism noted in not so distant an area, could not, after all, remain unnoticed by linguists.

In almost any handbook on the methodology of sciences the contemporary conception of truth is given much space (cf. e.g. Grobler 2006). A synthetic and a very apt presentation of the three circles of thinkers advocating alternative perspectives on truth is given by Kołakowski in his essay entitled Jest-że dla prawdy przysztość jaka? ("Is there any future for the truth?") (Kołakowski 2008).

The first circle are the scholars who support the classical Aristotelian theory of truth as a correspondence between the thought and reality (veritas est 
adcequatio rei et intellectus). This perspective was in the previous century modified under the influence of Tarski (1995) and it functions today in the shape of a formula: sentence A is true, therefore sentence A affirms that this is so and indeed it is so. For example, the sentence In winter days are shorter here than in summer is a true sentence - it states that in winter days are shorter here than in summer, and indeed IN WINTER DAYS ARE SHORTER HERE THAN IN SUMMER. Kołakowski (2008) describes such a conception of truth with an attribute correspondence, which he takes into inverted commas. Similarly to him, I will not analyse the problems solved by the thinkers who accept the above perspective as I assume that the reader's knowledge of such a classical approach to the conception of truth is quite well established.

As for the second circle, Kołakowski includes there the thinkers who opt for the coherence theory of truth. Within this framework it is assumed that each sentence functions in a whole coherent system of sentences. A concrete sentence is true if it is coherent with other sentences of the system. Moreover, it is obvious that evaluation applies also to whole systems, which can be numerous. This causes a problem of criteria of the system evaluation in which the analysed sentence was formed.

A fairly large group of philosophers hold a view at times referred to as arch-rationalism, which states that the choice of the system is made with the help of final and irrevocable criteria. Grobler (2006: 280) calls their approach absolutism, and he at the same time describes this group of thinkers with the name the intellectual right (in opposition to postmodernists described as the intellectual left). The arch-rationalists are in fact followers of the correspondence theory of truth, they do see that some propositions should be analysed in the context of other propositions belonging to the same system, at the same time, however, they are convinced that there exist final and irrevocable criteria of selection for one and only one system of propositions. It is within this system of propositions that it is possible to speak about the truth of propositions as of conformity with reality.

The author of this paper is an advocate of the so-called moderate rationalism, which speaks about relative, though rationally justified, criteria of selection. In my earlier work (Bobrowski 1993), based on Dąmbska's texts (e.g. 1937), I assume that we will find many extra-rational opinions in linguistics, as after all it is the task of metalinguistics to either include such opinions in a coherent system of propositions or indicate their unsolvable character, while at the same time postulating their elimination from linguistic reasoning. In the philosophy of linguistics which I currently follow the relations between sentences which are justified rationally and those for which it is difficult to find such a justification look far more complicated. I return to this issue towards the end of the article.

The third circle of thinkers is ever growing today; they can be well described with the help of the attribute pragmatic. It is at the same time fairly diverse internally. Some representatives of pragmatism are close to the coherence theory of truth, but in their consideration of the system selection criteria they are moti- 
vated by the system usefulness. Others, on the other hand, are inclined to believe that truth is a sociological category - this is true what the community of scholars recognise as true at a given moment. The community of scholars may be wrong in their evaluation of sentences. Thus, it is here that one should look for the source of the postmodernist views adduced to at the beginning of the article, according to which sentences formulated within some science (particularly within the humanities) are only peculiar (meta)narratives. Further in the text, when I discuss the pragmatic conception of truth, I will bear in mind its sociological and communicative understanding.

One needs to add here that the discussion which we are witnessing today often is more an ideological than an epistemological dispute. It is best illustrated in the paper by Dawkins (2003). To those who doubt the universal law of gravitation the author suggests that when flying to an academic conference they should try to jump out without a parachute from the height of several kilometres. Such a presentation of the truth issue has, after all, all the hallmarks of dogmatism, which I already mentioned at the beginning of our discussion. A much more constructive one is the stance taken by Grobler (1999). In the contestation of the traditional conception of truth this rational methodologist and philosopher of science perceives a very important factor of the development of the scientific reflection. Such a view is very close to the one taken by the author of this paper.

\section{Coexistence of different views in linguistics}

\subsection{Analytical assumptions}

After this fairly general introduction let us move to some specific questions. Let us reflect on the essence of propositions functioning in a field of knowledge which we will conventionally describe as linguistics. We will analyse sentences which are very deeply fixed in the consciousness of Polish linguists, as they belong to those which very often appear in the education of each Polish linguist. However, as it turns out, these sentences are of a very diverse nature. And it is not only that some of them concern grammatical issues from the area of the Polish language, whereas others contain observations concerning linguists' views. We will thus analyse sentences which are elements of something that could be described in a modern way as a Polish linguistic discourse (cf. Bobrowski 2005).

Before, however, we take up the analysis of those propositions, let us establish, for the sake of this deliberation, the scope of the three areas featuring here, i.e. metalinguistics, methodology of linguistics, and philosophy of linguistics.

Żmigrodzki (2006) finds a very fitting analogy between metalinguistics and literary criticism. In this way he postulates that metalinguistics should deal with the reviewing and criticism of linguistic works. Thus, metalinguistics would not be a methodology of linguistics but a set of more or less intuitive reflections of the researcher on the science which he and other linguists practice. As it seems, 
such an understanding of metalinguistics may also include works in the area of the history of linguistic thought.

As far as the two remaining areas are concerned, however, it has to be stated right away that the boundary between them is quite fluid. At the moment, methodology is distinguished from philosophy of science (Heller 2009), and the scope of the former is assumed to be defined by the more detailed issues concerning the perception of the subject matter of academic investigation and formulating propositions about this subject, while the task of the latter is to form more general views concerning the very assumptions of a given science as well as its connection with the philosophical reflection. The recent works by Bogusławski, and particularly his book from 2007 certainly belong to philosophy of linguistics. This article may also be recognised as an example of this field. With regard to views which are scrutinised in it, they may be recognised as belonging both to linguistics and metalinguistics - I describe them provisionally as sentences belonging to linguistics.

Not supporting any particular philosophical conception of truth of propositions, from among the linguistic propositions I know, I select those which may be recognised as true by the advocates of the correspondence theory of truth, while at the same time I note those which cannot be included in this approach. Further, I discuss the propositions which do not fit in there and analyse them from the point of view of the coherence theory of truth. Some propositions from this group do fulfil the requirements put by the advocates of the coherence conception of truth. However, I also identify such propositions which do not meet such criteria, although in the eyes of many linguists they are true propositions. They only fulfil the sociological conditions of truth and thus are mere components of the linguistic narrative. At the same time it is difficult to imagine linguistics without the coexistence of propositions from the three different sets singled out in the aforementioned way. I return to this problem at the end of my paper.

\subsection{Linguistic propositions which may be recognised as true by the advocates of the correspondence theory of truth}

After a deeper reflection advocates of the correspondence theory of truth may find it difficult to decide whether to recognise many propositions which at first sight appear to be candidates fulfilling their expectations as true. They will have least difficulties in the case of sentences concerning linguistic facts. However, they will by all means recognise the following sentence as true:

The sequence of sounds Pies gryzie kość ('The dog is gnawing a bone') belongs to the Polish language.

In any case, they will come across fewer obstacles in their reasoning than when they are to evaluate the following proposition:

The expression Pies gryzie kość ('The dog is gnawing a bone') is a Polish language sentence. 
The word (term) expression is more troublesome than the term sequence of sounds. The term sentence will prove even more troublesome for them. The term sentence must be defined with the help of a reference to other linguistic terms, and these always concern some abstract language model. Anyway, language is also an abstract entity, which cannot be scrutinised directly.

On the above assumption, in the aforementioned book Jezykoznawstwo racjonalne (Rational linguistics - Bobrowski 1993) I was ready to recognise all the propositions belonging to linguistics as true only within the coherence theory of truth, as all propositions are formed within some abstract model of language system. Such models can be unlimited in number. Thus, recognising some propositions formed within a model as true according to the correspondence conception of truth would require an assumption that there are final and irrevocable criteria of recognising this model as the best of all the possible ones. As has already been said, finding such criteria exceeds the framework of the methodology of linguistics accepted by me.

However, my standpoint has been somewhat modified, as it seems that there exist such linguistic propositions which may be included in all the imaginable language models. Thus, the proposition:

The nominative plural of the noun DOM ('house') takes the form domy ('houses').

although it contains some model constructs as nominative, plural, it may be recognised as true within the correspondence conception of truth, as no imaginable model of the Polish language can exclude these constructs, or constructs named differently, but having an identical meaning. By virtue of similar arguments, it is possible to recognise the following sentence as true within the correspondence conception of truth:

The verb GARDZIĆ ('despise') demands that the dependent noun takes the form of the instrumental.

or the sentence:

Verbs in Polish are inflected for person.

In the case of some sentences, their apparent opposition may get eliminated by means of referring to other meanings of the terms used in them. In the pair of sentences:

All Polish nouns are inflected for case.

Not all Polish nouns are inflected for case.

the form are inflected was used in two different meanings. The first sentence is true within the correspondence theory of truth when we accept that are inflected means the same as 'they take syntactic values of the case', while the second sentence may be recognised as true on assumption that are inflected has the same sense as 'include at least two different forms in their model of inflection'. In the Polish language there is, for instance, a noun DRZWI ('door'), which has all the forms syncretic, and thus it is not inflected according to the second sense of the verb inflect. Its having only one form does not, however, prevent the noun from taking different values of the case, e.g. the nominative (drzwi się zamknęty 
'the door closed') or the accusative (chtopiec zamknat drzwi 'the boy closed the door').

\subsection{Linguistic propositions which may be recognised as true only by the advocates of the coherence theory of truth}

However, we will find many propositions in linguistics whose truth may be stated only after the coherence conception of truth has been accepted. There exist such propositions formed in a certain system of propositions which are contrasted by propositions created within a different system, and the differences are motivated by some deeper reasons than the terminological ones.

Let us consider some sentences concerning the grammatical gender in Polish, which was already mentioned earlier in the text:

There are three types of the nominal gender in Polish: masculine, feminine, and neuter.

There are five types of the nominal gender in Polish: masculine personal, masculine animate, masculine inanimate, feminine, and neuter.

The gender of the noun in Polish depends on its number; in the singular the noun takes either the masculine gender, or the feminine gender, or the neuter gender; in the plural it takes either the masculine personal gender or the nonmasculine gender.

All these three sentences are true according to some grammatical models of the Polish language. The first sentence is true within the system of sentences determining the so-called traditional model. The second, on the other hand, is true in the system of sentences which can be named the Witold Mańczak model (Mańczak 1956), the third sentence is true in the grammatical model postulated earlier by the author of this article (cf. Bobrowski 1998), among others, and recently by Bogusławski (2009). In addition, the first sentence is also true according to my newest conception of the Polish gender (cf. Bobrowski 2006).

Thus, we have four linguistic models, i.e. systems of propositions within which one needs to consider the truth of the three above sentences. The first sentence is true according to two models, the second according to one model and the third also according to one model. At the next stage of investigating the truth of the three above sentences it is then necessary to evaluate the four linguistic models.

A number of hierarchies of criteria for the evaluation of linguistic models have been considered within the framework of linguistic methodology. The first level of all these hierarchies is uncontroversial. If linguistic models are not internally contradictory, it is necessary to focus on their completeness, that is, to evaluate their descriptive adequacy.

However, out of the four models only the traditional model proves to be incomplete as it does not describe the accommodation in the following combinations: widze dobrego pana ('I can see a good master'), widze dobrego kota ('I can see a good cat'), widze dobry stót ('I can see a good table'), widze dobrych panów ('I can see good masters'), widze dobre koty ('I can see good 
cats'), widze dobre stoty ('I can see good tables'). The syntactic rules demand that the adjective takes the case, the number, and the gender of the noun. In the first three combinations we have three different nouns, but according to the traditional model they would possess identical parameters, i.e. the accusative case, the singular number, and the masculine gender. Thus, in the first three combinations the adjective should have an identical form, whereas there are two forms of the adjective used there (twice dobrego and once dobry). In the other three combinations three different nouns would also possess identical parameters, the accusative case, the plural number, and the masculine gender. The adjective should therefore also take one form, however, it takes two (once dobrych, twice dobre). Let us note at this point that in the case of the first three sentences the personal noun in the singular pan ('master') and the animate noun kot ('cat') demand a different form of the adjective than the inanimate noun does, whereas in the case of the three other sentences the personal noun in the plural pan ('master') requires a different form of the adjective than the one which is imposed on it by the animate noun kot ('cat') and the inanimate noun stót ('table').

From this point of view the Witold Mańczak model, which postulates the distinction between the masculine personal gender, the masculine animate gender, and the masculine inanimate gender, is able to describe the morphological accommodations in the above sequences. Thus we say that the metalinguistic level demands that the proposition There are three grammatical genders in Polish be recognised as false. Its falsification takes place at the level of studying the Polish language.

One needs to pay attention to the fact that not only the Witold Mańczak model describes the relation of accommodation in the above six sentences properly. They can also be accounted for by the model which assumes the existence of three nominal genders in the singular and two in the plural, as well as the model postulated by me, which assumes the existence of only three nominal genders, but at the same time allowing for the gender to consist of sub-genders. We can thus say that on the level of the evaluation of the model of completeness we have rejected only one out of the four conceptions of the grammatical gender of nouns in Polish as incomplete, we still cannot, however, recognise any of the three propositions with which we began the discussion about gender as untrue.

Therefore, we must step onto the next level of the hierarchy of evaluating grammatical models and search for some possible solution of the problem there. The issue, however, proves to be quite complicated because on the higher level of hierarchy there is either a criterion of simplicity suggested by Hjelmslev (1953), of little use to us, which was then turned into an equally enigmatic criterion of the elegance of description, or an even less useful criterion of explanatory adequacy suggested by Chomsky (1964 and 1965). In the book, mentioned earlier, entitled Jezzkoznawstwo racjonalne (Rational linguistics) (Bobrowski 1993: 29) I instead put forward a criterion, in agreement with which the supremacy of grammatical models is established according to their degree of explicitness. It appears, however, that there is not much sense in considering these criteria because in each of the three enumerated grammatical models it will be quite 
possible to both find arguments speaking for their supremacy, and enumerate the flaws of each of them.

It is therefore necessary to accept that there exists a sizeable set of linguistic propositions which we can discuss only from the point of view of the coherence theory of truth. It is only some of them that we are able to finally recognise as false, following the metalinguistic criteria. Many of them do not yield themselves to such an evaluation. Thus we say that they are true within a strictly defined linguistic model, and when shifted to another model they become false propositions.

\subsection{Components of narratives}

Among propositions which exist in the scientific circulation it is also possible to find such ones whose truth cannot be demonstrated either within the framework of the correspondence conception of truth or within the coherence conception of truth. They are recognised as true by a given community of researchers - almost each scholar working on a given issue is able to quote them faultlessly, as they are indispensable components of communication between the scholars. The truth of these sentences results from the pragmatic theory of truth in its extreme sociological formulation.

At a certain point of time an opinion about breaking off with the Aristotelian tradition in the process of language categorisation was recognised as pragmatically true. A thesis was repeated in various books (cf., among others, Tabakowska 1995), but also Stefański (2001: 20) that "cognitivism breaks off with the traditional Aristotelian categorisation, which assumes the existence of sharp boundaries between categories, and introduces the prototype-based categorisation." This proposition cannot be recognised as true within the framework of the coherence conception of truth as it overlooks the theory of analogy, initiated precisely by Aristotle, and in later centuries developed creatively by his commentators and imitators (cf. Krapiec 1985). Aristotle noticed that some specimens may be classified in a certain category by means of analogy to other specimens fitting in this category. If this is the case, then he allowed for the structure of the category to be heterogeneous, whereby some specimens belonged there "directly", while others by virtue of analogy. It has to be added here that the theory of analogy was very elaborate. Possibly even a few hundred analogies were found which received their own names.

In a different essay I analyse a proposition concerning the idea of the phoneme developed by Baudouin de Courtenay, formulated by Jakobson, and universally recognised as true. According to many scholars the views upon the phoneme presented by Baudouin de Courtenay may easily be divided into those which are pioneering with regard to contemporary phonology as well as those which are rather regressive. This concerns the view about the psychic image of 
the phoneme. This view was most clearly expressed by Ivić (1975) in the two following excerpts of her very well known book Kierunki w lingwistyce (Trends in linguistics):

Even the first modern conception of the phoneme was born in the Kazan's period; later, however, Baudouin de Courtenay renounced it (Ivić 1975: 97).

Already in 1870s Baudouin de Courtenay clearly promoted the view that values of sounds tend to be used for distinguishing meanings. While developing his thought, Kruszewski (sometime in the 70s) stressed that phonemes were phonetic units with a particular function in communication between people. However, as early as 1894 Courtenay abandoned his previous phonetic principle in the definition of the phoneme. Under the influence of the psychologism of his era he gradually moves towards the psychological definition of the phoneme and defends it until the end. In the final version of Baudouin's conception the phoneme is a psychic image of the sound which, as an invariant category, contrasts with the variable one - a concrete, physiophonic realisation of the psychic image, i.e. a concrete sound [with regard to this Baudouin divides phonetics into physiophonetics - the study of investigating concrete sounds, and psychophonetics, whose subject is the psychic image of the sound]. This view is in keeping with what in the $19^{\text {th }} \mathrm{c}$. German scholarship was described as the Sprachgebilde/Sprachakt relationship. It does not in the least correspond to the contemporary conception of the phoneme [my emphasis, IB] (Ivić 1975: 133-134).

The source of this narrative is a well-known (as it was also translated into English) article by Roman Jakobson "The Kazan's School of Polish Linguistics and its place in the international development of phonology," first published in Biuletyn Polskiego Towarzystwa Jezzykoznawczego ("The Bulletin of the Polish Linguistic Society") in 1960. In this article Jakobson demonstrates that as early as 1868 Baudouin proves that phonetic differences between consonants tend to be used for the sake of differentiating meanings. From here it was not far to the question of indivisible phonetic units and the search for phonetic atoms. He already worked on these issues with Kruszewski. Finally, they both together addressed the question of studying the alternation of phonetically different, but etymologically related sounds.

Thus, for Baudouin and Kruszewski the phoneme was - as Jakobson remarks - a concept with a broad scope. A continuation of the way of thinking which both Poles initiated belongs today (i.e. in the 1960s) to phonology and morphonology.

Towards the end of the century there is, according to Jakobson (1971: 419), a fundamental change in Baudouin's views. Among others, he writes about it as follows:

Here then is one of the numerous and striking paradoxes of the fin de siècle: Baudouin de Courtenay, the discoverer of one of the central concepts of modern linguistics, was convinced that he had provided a satisfactory theoretical definition of the phoneme in characterizing it as "the psychic equivalent of a sound."

In this way the linguistic problems were, according to Jakobson (1971: 419) moved "to the hazy area of introspection."

It is possible, however, to try and construe a somewhat different narrative about the phonological views of Baudouin de Courtenay which would be more 
"friendly" - to use a fashionable term today - for the Polish scholar. It results from the reading of various texts of the scholar, but first of all from the book entitled modestly Próba teorii alternacyj fonetycznych ("An attempt at a theory of phonetic alternations") (cf. Baudouin de Courtenay 1894).

We would probably have to begin by stating that in the case of Baudouin in his Kazan's period one can speak about the formation of the term phoneme as a certain abstraction, a set of distinctive features of the sound. Since, however, he did not point to the phonologically important features, he was not able to form their bundles, and thus he was unable to present any model of the phonological system of the natural language. What remained of that system was only a general vision and a belief that there are such phonetic features which are able to differentiate the meaning of words.

However, in the later period a concept emerges from behind his term phoneme which we would today describe with the word morphoneme. If we asked where in the language description model such a concept should be placed, we would experience serious problems. Such a concept belongs to morphonology, but it is a unit abstracted from a series of alternative variants of the morpheme. Putting the variants together gives us a series of alternations, and it is only on a higher level of abstraction that we postulate an entity which is a representative of the whole series - and in principle only its label. Even Trubetskoy characterised this notion as a complex representation of all the elements of the morphonological alternation (cf. Trubetskoy 1931, also Kowalik 1985 and 1997). Can he also be perceived as an epigone of the $19^{\text {th }}$ c. psychologism?

The concept of the morpheme may also be outlined with the help of its reference to other grammatical issues. Thanks to the conception of the morphoneme abstracted for my own use from the so-called "yellow" morphology (cf. Laskowski 1985 and Kowalik 1985) I tried (cf. Bobrowski 1999) to demonstrate the legitimacy of the argumentation presented by Kucała (1999) in his criticism of Skarżyński's views (1999). The latter demonstrates that the correctness arguments on the basis of which the form wytanczam ('I turn off') is classified as substandard have no right of existence in rational linguistics thus, not only wytaczam should be treated as a correct Polish spelling. The traditional arguments - let me quote - sound more or less as follows: The form wytanczam has no linguistic justification because in the Polish language there is no alternation from $q$ into $q$. However, as Skarżyński argues - we do not have the alternation from $q$ into $q$ here, but an alternation of the sound $o$ into $a$ in the group on (wytaczam) into an (wytanczam). And thus the correctness advocates' argumentation is refuted.

Kucała (1999) demonstrates, however, that the alternation of on into an in principle appears in only one pair (wy)taczam : (wy)tanczam, and cannot be observed in other pairs, e.g. wysqczać ('drain') : *wysanczać. Following his line or reasoning, it is shown that the barrier which does not allow for the appearance of the alternation in the pairs like wysaczać : *wysanczać is morphoneme $Q$, which symbolises the chain of alternations to which belong, among others, the phonic sequences on, en, whereas the sequence $a n$ does not. 
However, this presentation unavoidably brings to mind a question about the essence of the morphoneme. After all, it is only a label of the alternation chain. Baudouin answers himself that it is a psychic image or rather a psychic "equivalent" - later Trubetzkoy does a similar thing. Is it then justified to postulate that this answer of his is a return to the $19^{\text {th }} \mathrm{c}$. psychologism?

Today's natural phonology, which claims that behind the phonological processes there is a phonetic and a psychological reality could be provided as a context for Baudouin's answer [and this is in fact what Laskowski (1999) does in Encyklopedia językoznawstwa ogólnego ("The encyclopaedia of general linguistics") - in the entry Natural phonology], but I will not do it, because when this unfair narrative - in my view - was being formed, natural phonology did not yet exist. There would not appear an alternative narrative to the one initiated by Jakobson, but rather another narration about how some views perceived as oldfashioned in some period are elevated in the future.

However, at the time when Jakobson was beginning his studies on the Kazan's school of Polish linguistics, Hjelmslev's conception of the sign was known, and universally known were also the principles of phenomenological analysis. I think that Baudouin's answer may well be treated as a pioneering one in relation to the two other ideas.

In his story Jakobson (1971: 419) claims that "to be sure Baudouin's antiquated psychologism was fundamentally just camouflage to justify his discoveries in the eyes of contemporaries - and in his own eyes, since he also was a child of his epoch." From the point of view of today's science of cognition (cognitivism) psychologism is not antiquated at all. In the middle of the $20^{\text {th }} \mathrm{c}$. the views of Wundt certainly were for Jakobson a relic of intuitionism. Yet surely he could not apply this attribute to the phenomenological views voiced by Husserl. In his book entitled Wspótczesne metody myślenia ("Contemporary methods of thinking") Bocheński (1992) very highly praises the phenomenological method and considers it to be one of the most important methods from the present day point of view. These views, on the other hand, can be dated back to Brentano, a follower of whom was Twardowski. Moreover, it is known that in the middle of the previous century one of the main propagators of the idea of intentionality was Searle (cf. Kołodziejczyk 2002).

I would not place Baudouin de Courtenay's idea that the (mor)phoneme is a psychic image of the sound in the context of the $19^{\text {th }} \mathrm{c}$. psychologism, but rather in the ideological trend which dates back to Brentano, and the key to which is the term intentionality with reference to existence. At the end of the $19^{\text {th }}$ c. Twardowski - the founder of the Lvov-Warsaw school - introduced a distinction between the content and the object of representation to the philosophical circulation (cf. Twardowski 1992). In his essay $O$ treści i przedmiocie przedstawien ("On the content and object of presentations") which is said to have influenced the philosophical system of Husserl, Twardowski points out that the object exists independently of the mental acts. Talking about the content, however, one states the existence of what depends on the existence of the mental act. 
Perhaps then it would be worth attempting at the following conclusion resulting from our reasoning thus far. The object of representation of the (mor)phoneme are the alternations described by Baudouin de Courtenay, whereas the content of the (mor)phoneme is the representation, i.e. the psychic "equivalent" of the sequence of alternating sounds.

It is worth noting the similarity between the distinction made by Twardowski and the conception of linguistic sign postulated by Hjelmslev (cf. Hjelmslev 1953), who announced his works more or less at the same time when Jakobson's article about the Kazan's school was being written.

As is known, when "improving" the conception of the sign by de Saussure, Hjelmslev postulated that, on the one hand, a distinction should be made between the plane of content and the plane of expression, and, on the other, between the plane of form and the plane of substance. The sign then should - according to Hjelmslev - be analysed in terms not of two (as de Saussure did), but of four planes. The substance of the sign on the plane of content would be a concrete element of reality, and the form on the level of content is its mental representation. In turn, the substance on the plane of expression is a concrete sequence of sounds, while the form on the plane of expression is the mental representation of that sequence of sounds. Incidentally, it is noteworthy that a very similar interpretation of Hjemslev's conception can be found in the book by Ivić (1975: 191). However, she does not suggest at all that such a perception of the sound aspect of language means going back to the $19^{\text {th }}$-c. psychologism. Such a thesis would be, after all, a very difficult one to prove in any case.

Thus, since Jakobson's narrative can be contrasted with another, an equally probable one, it has to be admitted that neither of them fulfils the conditions imposed on true propositions within the coherence conception of truth. After all, both narratives search for their logical arguments in the universally known ideological trends, but they interpret their influence on the way of thinking of Baudouin de Courtenay differently. The difference between these narratives is in principle reduced to the fact that Jakobson's narrative is treated by many linguists as a true proposition, whereas mine is even by myself recognised as a narrative only. The first opinion is thus true from the point of view of the sociological theory of truth, and the second one is only a hypothesis which will probably never attain a comparable status.

$$
* * *
$$

The discussion so far may give the impression that among propositions which can be described as true within the correspondence and the coherence conceptions of truth there are only these which deal with language, whereas among the propositions which can be declared true within the framework of the pragmaticsociological conception of truth there are all those which belong to metalinguistics. Such a generalisation can be denied, among others, by the functioning in the so-called linguistic circulation of the following proposition concerning the history of the Polish language: 
The asynchronous pronunciation of nasal vowels before stop consonants began in the Polish language in the $19^{\text {th }} \mathrm{c}$.

which - in my view - cannot be declared true either in the correspondence or in the coherence theory of truth, despite the fact that this proposition is considered true by many linguists.

In a different paper (Bobrowski 2000) I present a more complete argumentation to support the thesis that one can equally well discern the origin of the asynchronous pronunciation of nasal vowels in Old Polish. Since today the laboratory research does not leave any doubt as to the fact the Poles pronounce the word dęby ('oaks') as [demby], nothing should stand in the way to search for the beginnings of such articulation not in the modern times, but in a very remote past. However, neither the sentence with which we initiated this discussion nor the sentence that the process began in the Middle Ages can be ultimately negated. However, it is the truth of the former sentence that the linguists believe, while they doubt the latter. Thus, the former is an element of the linguistic narrative, while the latter cannot be a part of it.

\section{Conclusion}

The differences between my beliefs presented in Językoznawstwo racjonalne ("Rational linguistics") and the current views consist primarily in the fact that earlier, following Dąmbska, I treated the propositions which would yield to evaluation only from the point of view of the pragmatic-sociological conception of truth (I described them as extra-rational), as accidental, "entangled in science" - necessary to be eliminated from "ideal" linguistics. At present I believe that practicing linguistics is impossible without them, as they are a necessary component of linguistic discourse. Linguistic education would be completely ineffective without them and also the linguistic works which do not include references to these sentences would be completely incomprehensible. However, a constant reflection on the character of the propositions constituting linguistic discourse, and thus a reflection in the field of philosophy of linguistics, is needed.

In my Językoznawstwo racjonalne ("Rational linguistics") I also assumed that the truth of all the propositions from the area of linguistics can be evaluated only from the point of view of the coherence conception of truth. Currently I also notice the existence of a considerable set of sentences which can be recognised as true by the advocates of the correspondence theory of truth. Earlier I was inclined to assume that there existed rational and sufficiently effective criteria of evaluation of linguistic models which would allow for selection of the best of the existing models. Therefore, such criteria of evaluation undoubtedly belonged to the methodology of linguistics. At present I believe that these criteria are rather components of the philosophy of linguistics. Although they do not solve many controversial issues, they should still accompany any linguist in the process of formulating views concerning the structure of language. 
A question then appears as to whether such linguistics which I am now proposing may still be described with the attribute rational. It seems that the positive answer results mainly from the fact that I explicitly assume that on the level of the philosophical linguistic reflection the researchers should be able to define the three circles of sentences belonging to their discipline, and also every time determine the status of the propositions created by themselves or received from other investigators of propositions. They possess a cognitive apparatus on the basis of which they will be able to recognise some propositions as belonging to the centre of linguistics, assign others to the second circle, i.e. to the group of propositions recognised as true within the framework of the strictly defined linguistic model, and still acknowledge others as indispensable components of their discourse, although they will have no sufficient rational basis to recognise those propositions as fitting among the sentences fulfilling the criteria imposed by the followers of the coherence conception of truth.

$$
* * *
$$

It appears that this article leads to a conclusion of a more general nature. The thesis about the narrative character of the humanities was born in the area which is situated on the borderline between philosophy and history of ideas. Thus the very nature of views formulated within these fields, and particularly the latter, is very similar to the views propagated in metalinguistics. Thus the scholars who continually have to deal with propositions which do not yield themselves to evaluation even within the coherence theory of truth may easily pass from extreme scepticism and from a particularly critical attitude to the humanities as such. In postmodernists' books Grobler (1999) sees a sophisticated parody of scientific works. I have a similar impression when reading Rorty's texts (e.g. Rorty 2007).

From this parody rationalists should draw a conclusion that it is necessary to examine the basic propositions belonging to the centre of the practiced discipline very thoroughly. At the same time it is important to look for clear boundaries between propositions which yield themselves to assertion and propositions which at the present stage of scientific reflection are only elements of a (meta)narrative.

\section{References}

Baudouin de Courtenay J.N. 1894. Próba teorii alternacyj fonetycznych. - Rozprawy Wydziału Filologicznego PAU 20. Kraków: 219-364.

Bobrowski I. 1993. Językoznawstwo racjonalne. Kraków.

Bobrowski I. 1998. Gramatyka opisowa języka polskiego [vol. II: Od struktur wyjściowych do tekstu]. Kielce.

Bobrowski I. 1999. O kulturowej wartości gramatyki tradycyjnej i poradnictwa językowego (na marginesie artykułów P. Żmigrodzkiego i M. Skarżyńskiego). - Język Polski LXXIX: 399-402. 
Bobrowski I. 2000. Wiedza historycznojęzykowa a opisy polszczyzny współczesnej. - Rymut K., Rzepka W.R. (eds.) Studia historycznojęzykowe III. Kraków: 21-28.

Bobrowski I. 2005. O współistnieniu odmiennych dyskursów lingwistycznych. - Polonica XXIV-XXV: 5-19.

Bobrowski I. 2006. Jeszcze o rodzaju gramatycznym rzeczownika. - Polonica XXVI-XXVII: 231-243.

Bobrowski I. Uwagi o niesprawiedliwej opowieści na temat pewnych poglądów lingwistycznych Jana Baudouina de Courtenay. - Polonica XXX. [in press].

Bocheński J.M. 1992. Wspótczesne metody myślenia. Poznań.

Bogusławski A. 2007. A study in the linguistics-philosophy interface. Warszawa.

Bogusławski A. 2009. On case, gender and related phenomena in Polish (for the umpteenth time). - Linguistica Copernicana 1(1): 13-75.

Chomsky N. 1964. Current issues in linguistic theory. The Hague.

Chomsky N. 1965. Aspects of the theory of syntax. Cambridge (MA).

Dawkins R. 2003. A devil's chaplain: reflections on hope, lies, science, and love. Phoenix.

Dąmbska I. 1937. Irracjonalizm a poznanie naukowe. Kraków.

Grobler A. 1999. Granice irracjonalności. - Heller M., Mączka J., Urbaniec J. (eds.) Granice nauki. Kraków: 172-179.

Grobler A. 2006. Metodologia nauk. Kraków.

Heller M. 2009. Filozofia nauki. Kraków.

Hjelmslev L. 1953. Prolegomena to a theory of language. Baltimore.

Ivić M. 1975. Kierunki w lingwistyce. Wrocław.

Jakobson R. 1960. Kazańska szkoła polskiej lingwistyki i jej miejsce w światowym rozwoju fonologii. - Biuletyn Polskiego Towarzystwa Językoznawczego XIX: 5-34. [The English translation in Jakobson R. 1971: 401-425].

Jakobson R. 1971. Selected writings. Word and language. Berlin, New York.

Kołakowski L. 2008. Jest-że dla prawdy przyszłość jaka? - Znak 11: 73-79.

Kołodziejczyk P. 2002. Między fenomenologia a cognitive science. Johna Searle’a teoria intencjonalności [ http://www.kognitywistyka.net].

Kowalik K. 1985. Morfonologia. - Gramatyka wspótczesnego języka polskiego. Morfologia. Warszawa: 59-95. [2nd ed. 1998].

Kowalik K. 1997. Struktura morfonologiczna wspótczesnej polszczyzny. Kraków.

Krapiec M.A. 1985. Język a świat realny. Lublin.

Kucała M. 1999. [in:] Skarżyński M. 1999. Między tradycją a zdrowym rozsądkiem. Uwagi o naszym piśmiennictwie poprawnościowym. - Język Polski LXXIX: 120-121.

Laskowski R. 1985. Podstawowe pojęcia morfologii. - Gramatyka wspótczesnego języka polskiego. Morfologia. Warszawa: 9-57. [2nd ed. 1998].

Laskowski R. 1999. Fonologia naturalna. - Polański K. (ed.) Encyklopedia językoznawstwa ogólnego. Wrocław: 167-168.

Mańczak W. 1956. Ile jest rodzajów w języku polskim? - Język Polski XXXVI: 116-121.

Pelc J. 2003. Czy językoznawców nie obchodzi prawda? - Bobrowski I. (ed.) Anabasis. Kraków: 195-199.

Popper K.R. 1997. Mit schematu pojęciowego. Warszawa.

Rorty R. 2007. Wittgenstein i zwrot lingwistyczny. - Homo Communicativus 1(2): 13-28.

Skarżyński M. 1999. Między tradycją a zdrowym rozsądkiem. Uwagi o naszym piśmiennictwie poprawnościowym. - Język Polski LXXIX: 112-120.

Stalmaszczyk P. (ed.) 2006. Metodologie jęzkoznawstwa. Podstawy teoretyczne. Łódź.

Stefański W. 2001. Wprowadzenie do językoznawstwa historyczno-porównawczego. Toruń.

Tabakowska E. 1995. Gramatyka i obrazowanie. Kraków.

Tarski A. 1995. Semantyczna koncepcja prawdy i podstawy semantyki. - Zygmunt J. (ed.) Pisma logiczno-filozoficzne [vol. I: Prawda]. Warszawa: 223-233. 
Trubetskoy N. 1931. Dedanken über Morphonology. - Travaux de Cercle Linguistique du Prague 4: 53-61.

Twardowski K. 1992. O treści i przedmiocie przedstawień. - Wybór pism psychologicznych i pedagogicznych. Warszawa: 83-130.

Żmigrodzki P. 2006. Metalingwistyka. - Stalmaszczyk P. (ed.): 57-73. 